УДК $159.96: 616.89$

https://doi.org/10.52058/2708-7530-2022-1(19)-425-432

Коляда Наталія Вікторівна кандидат психологічних наук, старший викладач кафедри психології, політології та соціокультурних технологій, Сумський державний університет, вул. Римського-Корсакова, 2, м. Суми, 40000, https://orcid.org/0000-0002-6108-3482

Гуйван Катерина Андріївна студентка, Сумського державного університету, вул. Римського-Корсакова, 2, м. Суми, 40000

\title{
ОСОБЛИВОСТІ ЕГО-СТАНІВ У ОСІБ ЮНАЦЫКОГО ВІКУ 3 РІЗНИМ РІВНЕМ СПІВЗАЛЕЖНОСТІ
}

Анотація. У статті розглядається актуальна проблема сучасної психології - особливості его-станів у осіб з різним рівнем співзалежності. Проаналізовано поняття співзалежності та его-станів в різних літературних джерелах, емпірично досліджено рівень співзалежності та его-станів, а також визначено зв'язок рівня співзалежності та его-станів. Зауважено, що визначення співзалежності відрізняються, але зазвичай включають високу самопожертву, зосередженість на потребах інших, придушення власних емоцій та спроби контролювати чи виправляти проблеми інших людей. Встановлено, що теорія особистості транзакційного аналізу допомагає зрозуміти, як люди демонструють свою індивідуальність у поведінці. Зауважено, що контрзалежність - це невивчена протилежність співзалежності. Контрзалежні звички виникають внаслідок нездатності (неможливості) пройти повною мірою у дитинстві два важливі процеси розвитку: прихильності та відділення. Були встановлені характеристики контразалежних осіб та формування конрзалежності. Практична значущість роботи полягає в тому, що отримані результати наукової роботи можуть бути використані для подальших досліджень поняття співзалежності в контексті транзакційного аналізу.

Ключові слова: співзалежність, сепарація, міжособистісна взаємодія, залежні стосунки, психологічні конфігурації, его-стани, особи юнацького віку.

Koliada Nataliia Viktorivna Candidate of Psychological Science, Senior Lecturer at the Depertment of Psychology, Political Science and Socio-Cultural Technologies, Sumy State University, Rymskogo-Korsakova St., 2, Sumy, 40007, 40007, https://orcid.org/0000-0002-6108-3482

Huivan Kateryna Andriivna Student, Sumy State University, RymskogoKorsakova St., 2, Sumy, 40007, 40007 


\section{THE PECULIARITIES OF EGO-STATES IN YOUNG PEOPLE WITH DIFFERENT LEVELS OF INTERDEPENDENCE}

Abstract. The article presents the current problem of modern psychology. It is the features of ego-states in people with different levels of interdependence. The concept of interdependence and ego-states in different literature sources is analyzed, the level of interdependence and ego-states is empirically investigated, and the connection between the level of interdependence and ego-states is determined. It has been noted that definitions of interdependence differ, but usually include high selfsacrifice, focusing on the needs of others, suppressing one's own emotions, and trying to control or correct other people's problems. It has been established that the theory of personality of transactional analysis helps to understand how people demonstrate their individuality in behavior. It is noted that counterdependence is the unexplored opposite of interdependence. Counter-dependent habits arise due to the inability (impossibility) to go fully in childhood, two important developmental processes: attachment and separation. The characteristics of counter-addicts and the formation of counter-dependence were established. The practical significance of the work is that the results of scientific work can be used for further research on the concept of interdependence in the context of transactional analysis.

Keywords: the codependency, the separation, an interpersonal interaction, dependent relationships, psychological configurations, the ego-states, persons of adolescence.

Постановка проблеми. На сьогодні аналіз літературних джерел свідчить про недостатню кількість досліджень співзалежності в психології. Співзалежність - це дуже суперечлива конструкція, яка використовується в популярних клінічних та дослідницьких роботах. Сучасні автори не йдуть далі описів, які свідчать лише про те, що таке явище існує в системі психологічного знання. В наукових публікаціях також представлено не достатньо новий опис поведінкових проявів і критеріїв співзалежності, а також експериментальних досліджень особливостей співзалежності осіб у сфері їх міжособистісного спілкування. В результаті співзалежність виявляється одним 3 найменш вивчених явищ в психології.

Аналіз останніх досліджень та публікацій. Сьогодні в працях щодо вивчення співзалежності можна знайти різне іï тлумачення переважно 3 відображенням адиктивного аспекту, зокрема, в роботах вітчизняних вчених Мілушина М. О., Жидко М. Є., Крамченкової В. О., Савчук О. М. та ін. Актуальність роботи зумовлена також недостатньою увагою до проблеми сценаріїв та моделей поведінки у людей із співзалежністю, оскільки співзалежність стосується не тільки окремих особистостей, а й суспільства в цілому, яке створює умови, що сприяють утворенню співзалежних відносин і їх передачі з покоління в покоління. Саме це і зумовило вибір теми нашого 
дослідження: «Особливості его-станів у осіб юнацького віку з різним рівнем співзалежності».

Мета статті: визначення особливостей его-станів у осіб юнацького віку 3 різним рівнем співзалежності.

Виклад основного матеріалу. У сучасній психології існує кілька підходів до пояснення співзалежності. Але, до цих пір не створена вичерпна i переконлива концепція його виникнення i розвитку. Відсутність єдиного теоретичного підходу призводить до того, що основна увага дослідників зосереджена на вивченні окремих аспектів розвитку співзалежної поведінки.

Якщо розглядати визначення поняття «співзалежність», то його ідентифікація складна. Науковці трактують термін, як «хвороблива прив’язаність» (О. Сімонова), «надмірна стурбованість» (В. Штандер), «аддикція відносин» (А. Шаеф), «психологічний стан» (Subby R.), «комплекс особливих рис характеру» (С. Вітілд), «залежність» (В. Москаленко), «набір засвоєних норм поведінки» (Р. Баркер). Однак спільним показником означених понять $є$ постійна концентрація думки на комусь або чомусь, залежність (емоційна, соціальна) від людини чи об'єкта.

Автор популярних книг з цієї проблеми в США М. Бітті зауважує, що співзалежність - це залежність від близьких людей, від їх настрою, поведінки, хвороби або здоров’я, їх любові чи ненависті. Він вважає, що це парадоксальна залежність, а також називає іiі хворобою, так як співзалежні люди діють, надходять або реагують як хворі. Співзалежність у них постійно прогресує, i поведінку таких людей формує у них звичку до саморуйнування [1].

В роботах Г. Грінберга [2], Дж. Смола [3] та М. Вебб-Фабеана [4] можна знайти дуже схоже визначення співзалежності в якості поведінки, що зумовлена мотивацією залежності від значущого іншого; співзалежну людину вважають партнером по залежності. Крім того, В. Менденхалл зазначає, що співзалежність - це напружено-вимушена заклопотаність чиїмось життям, яка веде до поганої адаптивної поведінки особистості [5]. У той же час, на думку С. Вегшнайдера-Круса співзалежністю можна вважати заклопотаність i екстремальну залежність (емоційну, соціальну та іноді фізичну) від людини або об'єкта; як наслідок ця залежність від іншої людини стає патологічною ситуацією, яка робить будь-які взаємини співзалежними [6].

Деякі вчені вважають, що співзалежна людина - це людина, яка зазнає труднощів у житті і бачить причину цих труднощів в зовнішньому плані, в проблемах значущого іншого, який $\epsilon$ залежним від чогось. Предметом залежності може бути алкоголь, наркотики, хвороба, думка інших людей i навіть особливості характеру. Співзалежна людина починає також страждати бути залежною від предмета залежності [7].

Сьогодні поняття «залежність» і «співзалежність» характеризує людей, які захоплюються не тільки алкоголем, а й іншими хімічними речовинами: кокаїном, марихуаною, тютюном, героїном i т. д. Крім того, сюди включаються і інші види нав'язливої поведінки: розлади харчування (анорексія 
і булімія), розлади сексуальної поведінки (гіперсексуальність), залежність від роботи (трудоголізм), розлади особистості препсихотичного і психотичного спектра, психоневрози (обсесивно-компульсивний розлад) тощо. Ці розлади зачіпають членів сім’ї залежної людини - співзалежних людей, які можуть страждати від нього так само сильно або навіть сильніше, ніж сам залежний [10].

Поняття співзалежності також було вивчено на основі транзакційного аналізу. Так, 3 точки зору транзакційного аналізу, співзалежність можна розцінювати як сценарій або як синдром пасивності, що частіше виявляється у жінок, ніж у чоловіків. Він проявляється покірною поведінкою, яка несвідомо зосереджена на намаганні задовольнити потреби від ранніх емоційних дефіцитів. Таким чином, сценарій посилює невирішені симбіози, запобігаючи власному розвитку людини. Пасивна поведінка проявляється у бездіяльності (механізм заперечення); зовнішній надмірній адаптивній поведінці (поведінка, орієнтована на інших та задоволення їхніх потреб) або так звана гра рятівника; емоційне стримування або навпаки збудження, а також непрацездатність та жорстокість, що проявляються через психосоматичні розлади, або через образливу поведінку зі сторони оточуючих [9].

Таким чином, проаналізована література дає нам підставу стверджувати, що термін «співзалежність» трактується різними авторами по-різному i розглядається через специфіку психологічного i поведінкового станів, вивчений набір поведінкових форм, порушення адаптації, хвороба, різні порушення особистості і т. д. Цей феномен має свою структуру та цикл і може негативно впливати на життя в цілому та на окремі його сфери.

Отже, в дослідженні взяли участь 76 осіб віком від 18 до 23 років чоловічої та жіночої статі, 3 них 42 жінки та 34 чоловіка. Для нашого дослідження нами були обрані дві методики: методика: «Шкала співзалежності Уайнхолд, CSIS» та методика: «Опитувальник функціональних его-станів. (Personal Styles Questionnaire)».

В результаті проведеного дослідження за методикою «Шкала співзалежності Уайнхолд, CSIS», нами було встановлено, що у респондентів переважає високий ступінь співзалежних моделей (рис. 1.).
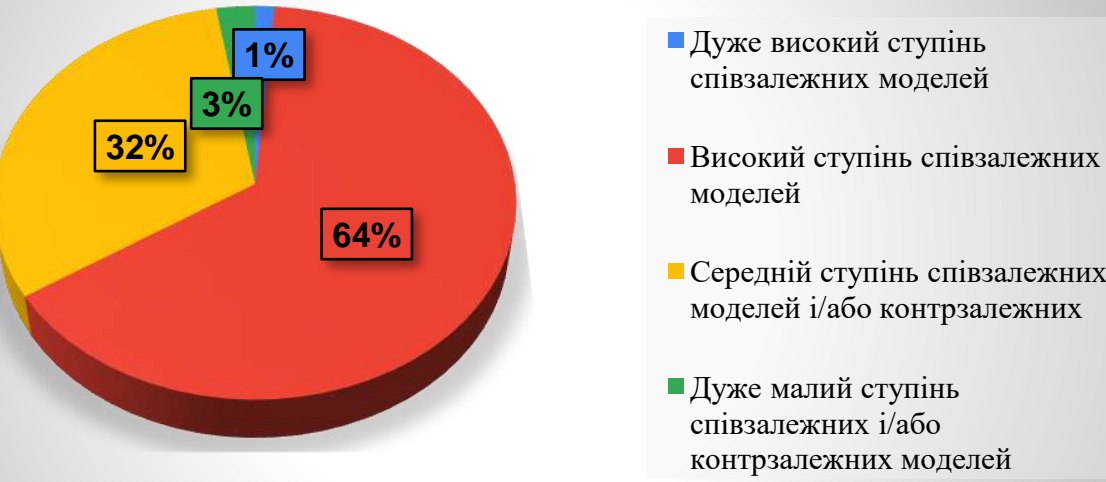

Pис. 1. Ступінь співзалежності серед усіх досліджуваних (у \%) за методикою «Шкала співзалежності Уайнхолд, CSIS» 
Можна висунути припущення, що більшість респондентів характеризуються надмірною тривожністю та підвищеною чутливістю. Лише $1 \%$ досліджуваних мають високий ступінь співзалежних моделей. Особливим $€$ те, що така співзалежність знаходиться на межі розладу особистості.

Встановлено, що у більшості досліджуваних чоловіків (65\%) і жінок (64\%) визначено високий ступінь співзалежних моделей (рис. 2). Ймовірно, такі люди можуть відчувати постійну потребу в схваленні оточуючих та не усвідомлювати своїх істинних бажань та потреб.

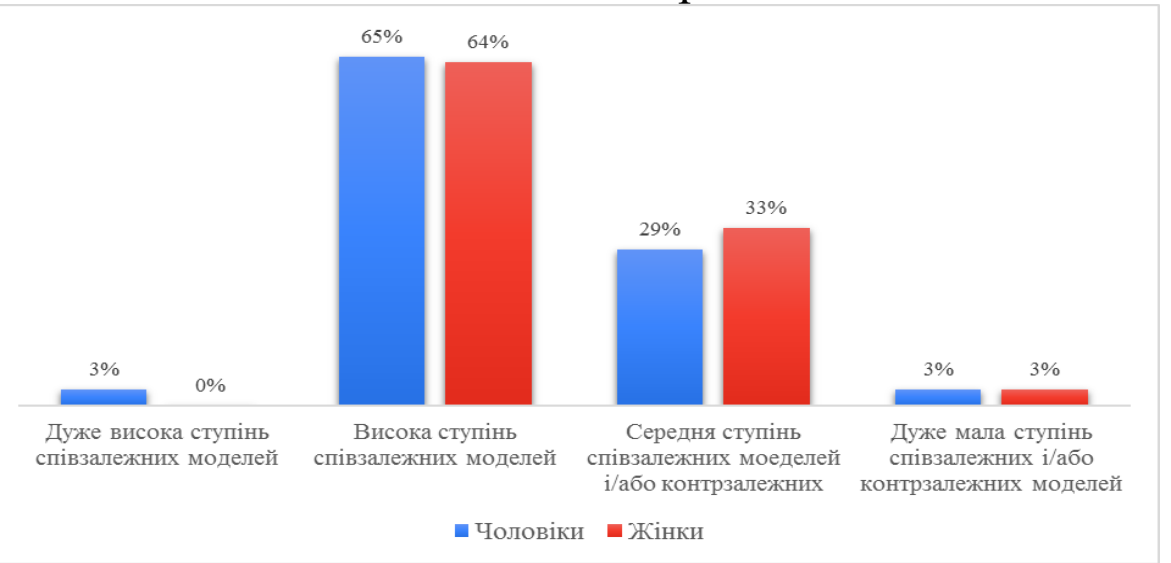

Pис. 2. Ступінь співзалежності серед чоловіків та жінок (у \%) за методикою «Шкала співзалежності Уайнхолд, CSIS»

Водночас, 29\% чоловіків та $33 \%$ жінок мають середній ступінь співзалежних i/aбо контрзалежних моделей. Відомо, що особистість із перевагою контрзалежних моделей буде уникати близькості, безперечно необхідної партнерові і йому самому, постійно віддаляючись і оберігаючи свою автономію, проте страх бути покинутим i невизнаним змушує контрзалежну особистість зберігати взаємини з іншою людиною. Також, слід відмітити, що дуже високий ступінь співзалежних моделей мають лише $3 \%$ чоловіків, і зовсім немає у жінок, що говорить про те, що для досліджуваної вибірки чоловіків характерна співзалежність, яка може перетікати в залежний розлад особистості. Низькій рівень притаманний $3 \%$ як жінкам, так i чоловікам.

Для перевірки чи $є$ різниця в показниках у осіб чоловічої та жіночої статті, нами був використаний Стьюдент-тест, який показав, що різниця між шкалами відсутня і дорівнює 0,82 . Тоді як кореляційний зв'язок дуже слабкий $(\mathrm{r}=0,18$ при $\mathrm{p}<0,05)$. Таким чином, можна сказати, що у переважній більшості респонденти відчувають потребу бути залежним від когось, відчувати емоційну прив'язаність, а для деяких характерні навіть межові стани особистості.

В результаті проведеного дослідження за методикою «Опитувальник функціональних его-станів (Personal Styles Questionnaire)» виявилося, що серед респондентів найбільш часто зустрічається его-стан «Дбайливий Батько» та «Дорослий» (по 27\% відповідно). Тобто для досліджуваних характерно 
надавати допомогу оточуючим, піклуватися про них та брати на себе відповідальність. У стані «Адаптивна Дитина» перебувають 21\% опитаних, які звикли адаптуватися до зовнішніх обставини, а не відстоювати свою позицію. Его-стан «Контролюючий Батько» притаманний 18\% людей, що говорить про те, що ця частина респондентів звикла критикувати та контролювати людей навколо себе. Та лише 7\% можуть відчувати себе вільними у своїх проявах та бажаннях (его-стан «Вільна Дитина»).

Аналізуючи дані респондентів чоловічої та жіночої статі, що представлені на рис. 3, можемо бачимо, що для чоловіків характерно переважання егостанів «Вільної Дитини», «Дбайливого Батька» та «Контролюючого Батька», що дає нам підстави думати, що чоловіки цієї вибірки безтурботні, неупереджені у своїх думках та діях, проте у стосунках, скоріше за все, проявлять себе як «хороший» або «поганий батько».

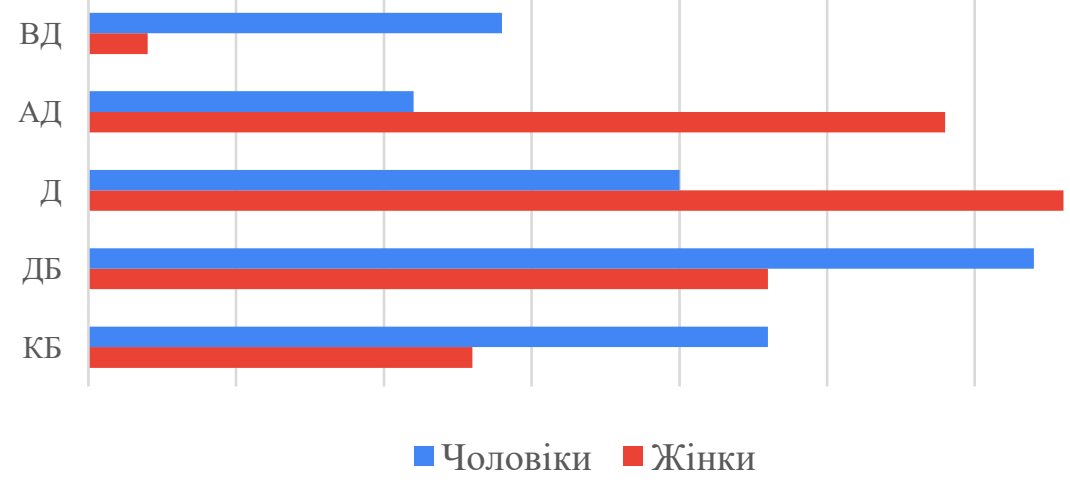

Рис. 3. Переважання его-станів серед чоловіків та жінок (у \%) за методикою «Опитувальник функиіональних его-станів. (Personal Styles Questionnaire)»

Цікавим є той факт, що більшість жінок вміють знаходитися в ситуації «тут і тепер» із використанням усіх ресурсів зрілої особистості («его-стан Дорослого»). Та деякі з них схильні підкорятися висунутим вимогам, адже мають его-стан «Адаптивної Дитини» (рис. 3). Для перевірки різниці між шкалами его-станів серед чоловіків та жінок ми зробили критерій Х-квадрат. За його підрахунком різниця між вибірками відсутня $(0,96)$.

Отже, бачимо, що для чоловіків характерно перебувати у стані контролюючого або дбайливого батька, та рідше вони поводять себе за «принципом задоволення». На відміну від чоловіків, жінки відчувають себе «дорослими», відповідальними, проте ховають свої справжні почуття, замінюючи їх дозволеними.

На наступному етапі роботи нами був використаний регресійний аналіз даних. Результати показали зв'язок співзалежності та его-стану «Адаптивної Дитини» $(\mathrm{k}=0,62)$ при $\mathrm{R}$-квадрат $=0,11$. Це говорить про те, що співзалежність характерна для $11 \%$ респондентів, 3 яких у 6\% спостерігається тенденція бути «Адаптивною Дитиною». Крім того, під час подальшого аналізу даних нами 
було виділено три шкали співзалежності на основі отриманих даних респондентів: 29-39 - низький рівень, 40-50 - середній рівень та 51-61 високий. А також визначено кореляційний зв'язок по кожному рівню (табл. 1.).

Табличя 1

Кореляційний зв'язок его-станів 3 різним рівнем співзалежності

\begin{tabular}{|c|c|c|c|c|c|c|}
\hline \multicolumn{7}{|c|}{ Високий рівень співзалежності } \\
\hline & КБ & ДБ & Д & АД & ВД & Співзалежність \\
\hline КБ & 1 & & & & & \\
\hline ДБ & $-0,087$ & 1 & & & & \\
\hline Д & $-0,063$ & 0,339 & 1 & & & \\
\hline АД & 0,528 & 0,241 & $-0,347$ & 1 & & \\
\hline ВД & 0,426 & $-0,107$ & 0,249 & 0,094 & 1 & \\
\hline Співзалежність & 0,446 & 0,267 & 0,208 & 0,353 & 0,245 & 1 \\
\hline \multicolumn{7}{|c|}{ Середній рівень співзалежності } \\
\hline & КБ & ДБ & Д & АД & ВД & Співзалежність \\
\hline КБ & 1 & & & & & \\
\hline ДБ & 0,634 & 1 & & & & \\
\hline Д & 0,659 & 0,613 & 1 & & & \\
\hline АД & 0,315 & 0,487 & 0,366 & 1 & & \\
\hline ВД & 0,561 & 0,529 & 0,469 & 0,272 & 1 & \\
\hline Співзалежність & 0,033 & $-0,157$ & $-0,015$ & $-0,101$ & 0,098 & 1 \\
\hline \multicolumn{7}{|c|}{ Низький рівень співзалежності } \\
\hline & КБ & ДБ & Д & АД & ВД & Співзалежність \\
\hline КБ & 1 & & & & & \\
\hline ДБ & 0,537 & 1 & & & & \\
\hline Д & 0,727 & 0,278 & 1 & & & \\
\hline АД & 0,597 & 0,37 & 0,573 & 1 & & \\
\hline ВД & 0,706 & 0,675 & 0,67 & 0,52 & 1 & \\
\hline Співзалежність & $-0,32$ & $-0,09$ & $-0,41$ & $-0,19$ & $-0,24$ & 1 \\
\hline
\end{tabular}

Таким чином, встановлено позитивну кореляцію високої співзалежності iз «Контролюючим Батьком» та «Адаптивною Дитини». В той час як на низькому рівні співзалежності спостерігається зворотній зв'язок его-станів, особливо его-стан «Дорослий». Можна припустити, що чим нижчий рівень співзалежності, тим більше особистість вміє бути дорослою, а саме нести відповідальність за своє життя, вміти відстоювати свої кордони, $\epsilon$ психологічно зрілою. Також бачимо, що на високому рівні співзалежності «Контролюючий Батько» має прямий зв’язок із «Адаптивною Дитиною». Тоді як при низькій співзалежності «Контролюючий Батько» вже розглядається 3 позиції «Дорослого».

Висновки. Узагальнення одержаних результатів емпіричної складової дослідження дає змогу констатувати, що у осіб юнацького віку спостерігається наявність співзалежності на різних рівнях. Слід зазначити, що гендерних особливостей співзалежності не було виявлено. Це може говорити про те, що феномен співзалежності залежить від індивідуально-психологічних характеристик особистості, а не від гендерних особливостей. Виявлено 
тенденцію до високого рівня співзалежності. Встановлено, що для жінок характерні такі стани як «Дорослий» та «Адаптивна Дитина», в той час, як чоловікам притаманні стани «Контролюючого» та «Дбайливого» батька. Найрідше зустрічається стан «Вільної Дитини».

\section{תimepamypa:}

1. Beattie M. Beyond Codependency and getting better all the time. San Francisco: Harper \& Row, 1989. 252 p.

2. Greenberg G. The Self on the Shelf. State University of New York Press, 1994. 287 p.

3. Small J. Awakening in Time: The journey from Co-dependence to Cocreation. Bantam, New York, 1991. 288 p.

4. The Webb-Fabean. Codependence Assessment Guide. Princeton, 1993. 20 p.

5. Mendenhall W. Course on Co-dependence. New Brunswick, 1987. 400 p.

6. Wegschnider-Cruse S. Choice-Making. Pompano Beach, Florida: Health Communication, 1985. $206 \mathrm{p}$.

7. Артемцева Н. Г. Феномен созависимости: общее, типологическое, индивидуальное : монографія. Москва : «Институт психологии PAH», 2017. 227 с. URL: https://lib.ipran.ru/upload/papers/29724484.pdf (дата звернення: 12.11.2021).

8. Хемферт Р., Минирт Ф., Майер П. Выбираем любовь. Борьба с созависимостью. Триада, 2012. 320 c. URL: https://www.rulit.me/books/vybiraem-lyubov-borba-s-sozavisimostyuread-466368-1.html (дата звернення: 11.11.2021).

9. Schiff, J. L., Schiff, A. W. Cathexis reader: Transactional analysis treatment of psychosis. New York: Harper \& Row, 1975. 57 p.

\section{References:}

1. Beattie M. Beyond Codependency and getting better all the time. San Francisco: Harper \& Row, 1989. 252 p.

2. Greenberg G. The Self on the Shelf. State University of New York Press, 1994. 287 p.

3. Small J. Awakening in Time: The journey from Co-dependence to Cocreation. Bantam, New York, 1991. 288 p.

4. The Webb-Fabean. Codependence Assessment Guide. Princeton, 1993. 20 p.

5. Mendenhall W. Course on Co-dependence. New Brunswick, 1987. 400 p.

6. Wegschnider-Cruse S. Choice-Making. Pompano Beach, Florida: Health Communication, 1985. $206 \mathrm{p}$.

7. Artemceva, N. G. (2017). Fenomen sozavisimosti: obshhee, tipologicheskoe, individual'noe [The phenomenon of codependency: general, typological, individual]. Moskva : «Institut psihologii RAN» [in Russian].

8. Hemfert, R., Minirt, F., Majer, P. (2012). Vybiraem ljubov'. Bor'ba s sozavisimost'ju. Triada [Choosing love. Fight codependency. Triada]. www.rulit.me Retrived from https://www.rulit.me/ books/vybiraem-lyubov-borba-s-sozavisimostyu-read-466368-1.html [in Russian].

9. Schiff, J. L., Schiff, A. W. Cathexis reader: Transactional analysis treatment of psychosis. New York: Harper \& Row, 1975. 57 p. 